\title{
The Effect of Traditional Games and Free Play on the Motor Skills of Preschool Children
}

\author{
Jernice S.Y. Tan ${ }^{1^{*}}$, Karen P. Nonis ${ }^{2}$, Li Yang Chan ${ }^{3}$ \\ ${ }^{1}$ School of Sports, Health and Leisure, Republic Polytechnic, Singapore \\ ${ }^{2}$ School of Education, Curtin University, Perth, Western Australia \\ ${ }^{3}$ School of Sports, Health and Leisure, Republic Polytechnic, Singapore
}

Received: $23^{\text {th }}$ Oct 2020 Revised: $21^{\text {th }}$ Nov 2020 Accepted: $7^{\text {th }}$ Dec 2020 DOI: https://doi.org/10.31559/CCSE2020.1.2.6

Abstract: A child's play is critical to whole child development. However, literature related to how traditional games and unstructured free play is limited. This study investigated if traditional games and free play could influence the motor skills of preschool children. One hundred and ninety-two children (Traditional Group: $n$ $=114, \mathrm{M}$ age $=4.5 \&$ Play Group: $n=78, \mathrm{M}$ age: 4.7$)$ were recruited. Traditional Group played five types of traditional games while Play Group had free play over 20 sessions in 5 weeks. The MABC-2 was used to assess their motor skills. Data were analysed in three groups: All, performing 30 and Underperforming 30 . The results showed that all participants made significant improvements in balance and overall motor skills with either traditional games or free play. Within the Performing 30 category, the Traditional Group performed significantly better in manual dexterity and overall motor skills as compared with the Play Group. However, both groups improved significantly in manual dexterity, balance abilities and overall motor skills within the Underperforming 30 category. This suggested that irrespective of structured traditional games or unstructured free play, child's play has positive benefits on the development of motor skills especially for children with poorer motor skills.

Keywords: motor skills; traditional games; free play; structured play; preschool children.

${ }^{*}$ Corresponding author

Jernice S.Y. Tan

School of Sports, Health and Leisure, Republic Polytechnic, Singapore

E-mail: jernice_tan@rp.edu.sg 
International Journal of Childhood, Counselling, \& Special Education (CCSE), Volume1, Issue: 2, December: 2020, pp.204-223

\section{Introduction}

A child's play is critical to whole child development. Play is an important contributor to a child's life from childhood, through adolescence and to adulthood (Fleer, 2015; Nonis, 2005). During play, children develop language, social and cognitive skills as they became involved in divergent play and critical thinking (Nonis \& Tan, 2010). Communicating their feelings through social interactions with their friends would help them to make better sense of their world. Through play, social and emotional competency could be developed to prepare the child to cope with lifelong challenges (Mackenzie, 2007). Play promotes motor skill development and subsequently progresses to the physical activities and sport games that a child would engage at the later years. Under the ecological perspective, different play structures could be described as the environment settings under the Newell's (1986) model. The dynamic interactions of individual, task and environment contribute to the motor skill development of a child (Newell, 1986). Essentially, a child's play at early childhood stage can be categorised as structured and unstructured play.
Children and their different play structures:

The concept of free play and what it means to children, to parents and teachers can vary (Fleer, 2015). In this current study, we explored the notions of unstructured play. Unstructured play can be characterised as spontaneous, free flowing and may appear to be aimless which also include playing in the outdoors (Hewson, Mcconkey \& Jeffree, 1980). However, it is directed by the child's interests and curiosity in their learning environment. Unstructured play can be driven by the child with limited adult interference (Santer, Griffiths \& Goodall, 2007). In unstructured play, a child is said to be in complete control of making all decisions on his own and adults do not structure or organise the activities (Santer et al., 2007). A child typically develops positively from unstructured play (Parten, 1932). There are numerous benefits of unstructured free play for whole child development. During unstructured free play, children are able to freely explore various types of movement and physical activities. These unstructured sessions would also present opportunities for the children to reinforce and support the skills that they have learned during the structured lessons (Jones, Okely, Hinkley, Batterham \& Burke, 2016). Through these unsupervised physical activities, children may more likely be creative where their imagination 
International Journal of Childhood, Counselling, \& Special Education (CCSE), Volume1, Issue: 2, December: 2020, pp.204-223

runs wild with new ideas of how games can be played in different ways. Another strength of unstructured free play would be the ability to develop a child's ability to self-regulate his cognitive and emotional processes. Self-regulation plays an important role of child development and it can serve as a predictor of a child's emotional wellbeing (Barrerio \& Howard, 2017). Unstructured play typically starts as early as infancy. As a child grows older to about 4 years old, structured play begins to take precedence in child development (Parten, 1932). In this way, unstructured play can be compared to the developmental or maturational concepts in play (Dockett, 1999). Developmental views of play interpret the child's motivation and drive that children have in the process of play. Children construct their own meaning and develop meaningful learning experiences as they freely express themselves in their play behaviour.

Unlike unstructured play, the exact opposite is structured play which is often seen as externally controlled with specific learning objectives (Hewson et al., 1980). Structured play is seen to be controlled by adults of which they dictated the activity progression, rules and even participation intensity (Barrerio \& Howard, 2017). Organised sports such as basketball, soccer and netball could be examples of structured play which are taught in schools. The training programme of these organised sports are typically structured where the teacher determines the warm up protocols, the types of drills, the players' roles and the cool down activities. Structured play is beneficial because it builds the foundation skills which serve as the groundwork for longterm athletics performance (Faigenbaum, Lloyd, \& Myer, 2013). Without clear guidance and direct instructions, a child might not be able to develop proficient fundamental motor skills (FMS). Many intervention studies have shown that children, aged three to nine years old who experienced structured play or organised physical activities would make significant improvement in their motor skills (Bremer, Balogh, \& Lloyd, 2015; Deli, Bakle \& Zachopoulou, 2006; Goodway \& Branta, 2003; Goodway, Crowe, \& Ward, 2003; Hamilton \& Liu, 2018; Logan, Robinson, Wilson, \& Lucas, 2011; Robinson, Palmer, \& Meehan, 2017; Tortella, Haga, Loras, Sigmundsson, \& Fumagalli, 2016). Deli et al. (2006) examined the effects of different 10-week movement programmes on fundamental movement skills in kindergarten children. Group A followed movement programme which aimed to develop FMS, Group B engaged in a music and movement programme whereas Group C focused on free play activities. The main difference 
International Journal of Childhood, Counselling, \& Special Education (CCSE), Volume1, Issue: 2, December: 2020, pp.204-223

between Group A and B was the absence of rhythmic accompaniment in the movement programmes. The authors reported that children in both Group A and B who followed organised activities had improved their performance more than Group $\mathrm{C}$ who engaged in free play (Deli et al., 2006). Similarly, in Hamilton and Liu's (2018) study, the experimental group of pre-K children improved their fine and gross motor skills after 16 weeks (800-minutes) of planned motor intervention as compared to the control group who had play-based lessons without instructions.

\section{Children and Traditional Games:}

The proficiency of motor skills has an important role in games and activities, which come in a myriad of forms seen in traditional and current new age games. Prior to the rapid technological advancement that the millennials went through, growing up in Singapore encompassed of outdoor games and playground play. Traditional games were forms of structured play activities played by children. A proficient level of both fine and gross motor skills is required to play competently in most traditional games. In review of the cultural and historical models of play, Gonchu and Gaskin (2011) explained that children could draw from their unique growing environments as forms of play exploration. Traditional games in
Singapore were widely played in the past and commonly documented in the historical evolution of Singapore's heritage. Singapore's traditional games build coordination, agility, speed and reaction time which are critical and essential motor abilities for motor skill development. While the effectiveness of traditional games linking to motor skill development has had limited research attention, many records describing these games are written by the Ministry of Education, Singapore and are archived in the National Library of Singapore (MOE, 1998). Some of these games include Hantam Bola, Kuti-Kuti, Five Stones, Zero Point, Bola-Tin and Congkak, Chapteh, and Gasing.

Different types and varied ways of playing traditional games were observed in different countries. The Iranians played marbles (Tileh Bazi) and five stones (Ye Ghol Do Ghol; Sang, 2016). According to the National Department for Culture and Arts of Malaysia, the Malaysian traditional games include tossing the stones (Batu Seremban), long elephant (Gajah Panjang) and kicking the feathers (Sepak Bulu Ayam). Studies in both Iran and Malaysia reported positive improvements of the motor skills of their local children through traditional game play (Abdullah, Amri, Kok, \& Samah, 2013; Akbari, Abdoli, Shafizadeh, Khalaji, 
International Journal of Childhood, Counselling, \& Special Education (CCSE), Volume1, Issue: 2, December: 2020, pp.204-223

Hajihosseini, \& Ziaee, 2009; Ghipit @ Charles, Abdullah, Musa, Kosni, \& Maliki, 2017; Jaydari, Rouzbahani, \& Hasanvand, 2016).

Arkbari et al., (2009) explored the effects of traditional games on FMS development of children with poor motor skills (gross motor score of range 60 to 70 , equivalent to one percentile of norm population). At baseline, both groups have similar motor performance of nonsignificant differences $(n=40$, traditional group $=20$, control group = 20; age $7-8$ years old). At post-test, it was reported that children with traditional game intervention elicited a larger significantly improvement (3 out of 3 task components) than other children who had undergone daily activities. Further analysis revealed that these participants had a higher baseline as compared to the norms which might suggest that participants with different baseline would reap the same benefits. At an older age group, Jaydari (2016) investigated the effect of traditional games on the development of transfer and manipulative motor skills of Iranian boys with intellectual disabilities $(n=$ 20; Traditional group $=10$, Control group $=10$; aged 13 to 17 ). The intervention programme consisted of 24 sessions of 45-minute that were conducted three times a week over 8 weeks. Jaydari (2016) reported that traditional group demonstrated significant superiority as compared with the control group $(p<.05)$ in three out of 12 motor skills tasks (roll, horizontal jump \& kick) after intervention. This finding proposed that children with poorer motor proficiencies would find it easier to receive positive benefits from traditional game intervention.

Closer to the shores of Singapore, in Malaysia, Abdullah et al., (2013) evaluated the effectiveness of traditional games using the TGMD-2 (Ulrich, 2000) of 9-year-old children $(n=64$; Traditional Group: 16 boys \& 16 girls; Control Group: 17 boys \& 15 girls). Their findings reported that the Traditional Group made significant improvements for all three motor components (locomotion, manipulative \& GMDQ; $p$ <.05). A particular point worth noting was that Abdullah and authors (2013) had recruited children with under-developing motor skills (locomotor: age equivalents about 4.35 years \& manipulation: age equivalents about 4.63 years) while their chronological age was approximately nine years old. Although the authors did not describe the types of traditional games played, it was concurred that playing traditional games was helpful in the development of gross motor skills (Abdullah et al., 2013). It was further inferred that traditional games as a form of motor intervention worked significantly effectively for underperforming children who started off with lower 
International Journal of Childhood, Counselling, \& Special Education (CCSE), Volume1, Issue: 2, December: 2020, pp.204-223

than norm motor performance. The post intervention results exhibited improved motor skills (locomotor: age equivalent about 7.41 years \& manipulation: age equivalent about 7.17 years). Similarly, Ghipit @ Charles et al. (2017) investigated the effectiveness of traditional games intervention program on children's motor skill-related components. Their study reported significant improvement in motor skills due to participation in traditional game play for primary school-aged children $(n=$ 40; 20 females and 20 males; age range: $12-13$ years old). Only one out of four motor components had significant difference when compared within subjects. General improvements were seen in motor fitness performances after traditional game intervention. Specifically, the children improved significantly in their speed. But the study did not show significant improvements in the balance task component even though improved scores were seen using the modified bass test of dynamic balance (Ghipit @ Charles et al., 2017). Amongst the traditional game studies, most studies reported significant improvement in the majority or if not, all of the motor tasks. However, to date, only about four studies documented the use of traditional games as motor intervention (Abdullah et al., 2013; Arkbari et al., 2009; Ghipit @ Charles et al., 2017; Jaydari, 2016). Three out of four studies showed that significant improvements were found when traditional games were used as intervention. Consequently, some of these studies reported that underperforming participants experienced greater improvement than the performing participants (Abdullah et al., 2013; Arkbari et al., 2009).

Besides using traditional games as intervention, several motor interventions studies had also explored the impact of structured and unstructured play (Deli et al., 2006; Goodway \& Branta, 2003; Robinson et al., 2017; Tortella et al., 2016; Logan et al., 2011). Typically, the duration and frequency of intervention sessions ranged from 18 session to 45 sessions and conducted between three to five times per week. Results from these studies had shown that 18 to 45 intervention sessions were generally effective in improving the participants' motor skills (Deli et al., 2006; Goodway \& Branta, 2003; Logan et al., 2011; Robinson et al., 2017; Tortella et al., 2016). While the duration and frequency could be determining factors of intervention effectiveness, the use of different motor assessments could be another consideration too. Different studies used different motor assessments to evaluate intervention effectiveness (Goodway et al., 2003; Fisher et al. 2005; Logan \& Getchell 2010). Logan, Robinson, Rudisill, Wadsworth and Morera (2014) 
International Journal of Childhood, Counselling, \& Special Education (CCSE), Volume1, Issue: 2, December: 2020, pp.204-223

compared the motor performance of 65 children $(M$ age $=6.7$ years old $)$ with TGMD-2 (Ulrich, 2000) and MABC-2 (Henderson, Sugden, \& Barnett, 2007). The authors observed that children seemed to perform significantly poorer with TGMD-2 (Ulrich, 2000) due to its process-oriented nature as compared to MABC-2 which is productoriented assessment (Henderson et al., 2007). Logan et al. (2014) had proposed that it was possible that performance scores would be poorer using TGMD-2 as compared with MABC-2 because TGMD-2 assessed qualitative movement criteria of mastery level and required more advanced motor coordination and limb control.

The review of literature suggests that motor intervention studies using structured play including traditional games were commonly conducted for children aged seven to 17 years old (Abdullah et al., 2013; Arkbari et al., 2009; Ghipit @ Charles et al., 2017; Jaydari et al., 2016). However, to the best of our knowledge, the use of traditional games intervention on preschool children below seven years old has not been documented. The effect of unstructured play on motor skills improvement is also unclear. Therefore, the aim of this study was to evaluate the effectiveness of both structured play (i.e. traditional games) and unstructured (i.e. free play) on the motor skills of preschool children aged three to six years old. The research questions were:

1. Is there a significant improvement on the motor skills of preschool children after their 5-week intervention programme of either 1) traditional games or 2) free play?

2. Is there a significantly different effect on the motor skills of preschool children of different levels of motor performance after their 5-week intervention programme of either 1) traditional games or 2) free play?

\section{Methods}

\section{Participants:}

One hundred and ninety-two children $(n=192$; $M$ age: $4.5 \pm 0.9$ years; age range: 3 - 6 years), free from health conditions, physical injuries and physical disabilities, were placed in either Traditional Group $(n=114, M$ age: $4.5 \pm 0.8$ years) or Play Group ( $n=78, \mathrm{M}$ age: $4.7 \pm 0.9$ years). Unbiased and voluntary recruitment was done through direct briefings to clarify research aims, procedures and possible benefits to the children without prejudice. Parental consents and child assents were obtained via childcare centres and preschools. Ethics approval through the Institutional Review Board was sought before data collection. 
International Journal of Childhood, Counselling, \& Special Education (CCSE), Volume1, Issue: 2, December: 2020, pp.204-223

Instrument and Tasks:

The Movement Assessment Battery for Children - 2nd edition (MABC-2; Henderson et al., 2007) was used to assess the performance of motor skills using traditional games and free play. The MABC-2 consists of eight test items in every age band (age band 1: $3-6$, age band 2: $7-10$, $\&$ age band 3: $11-16$ years old). The eight test items of age band 1 (3 components - Manual Dexterity (MD): MD1 - posting coins, MD2 threading beads \& MD3 - drawing trails; Aiming \& Catching (AC): AC1 - catching beanbag, AC2 throwing beanbag; Balance (BAL): BAL1 - one-leg balance, BAL2 walking heel raised, BAL3 - jumping on mats) were used in this study. Children were given one practice, two trials and rest periods when needed during testing and took approximately 20 minutes to complete the test.

Intervention Programme:

The 5-week intervention programme, consisted of 20 times of 30-minute sessions, was conducted four times every week (see Figure 1). As most childcare centres and preschools preferred shorter research span, this 5-week intervention of 20 sessions were designed based on slightly more than the minimum recommended duration and frequency of existing effective intervention studies ((Deli et al., 2006; Goodway \& Branta, 2003; Robinson et al., 2017; Tortella et al., 2016; Logan et al., 2011). The Traditional Group and Play Group had different physical movement experiences during the 5-week intervention.

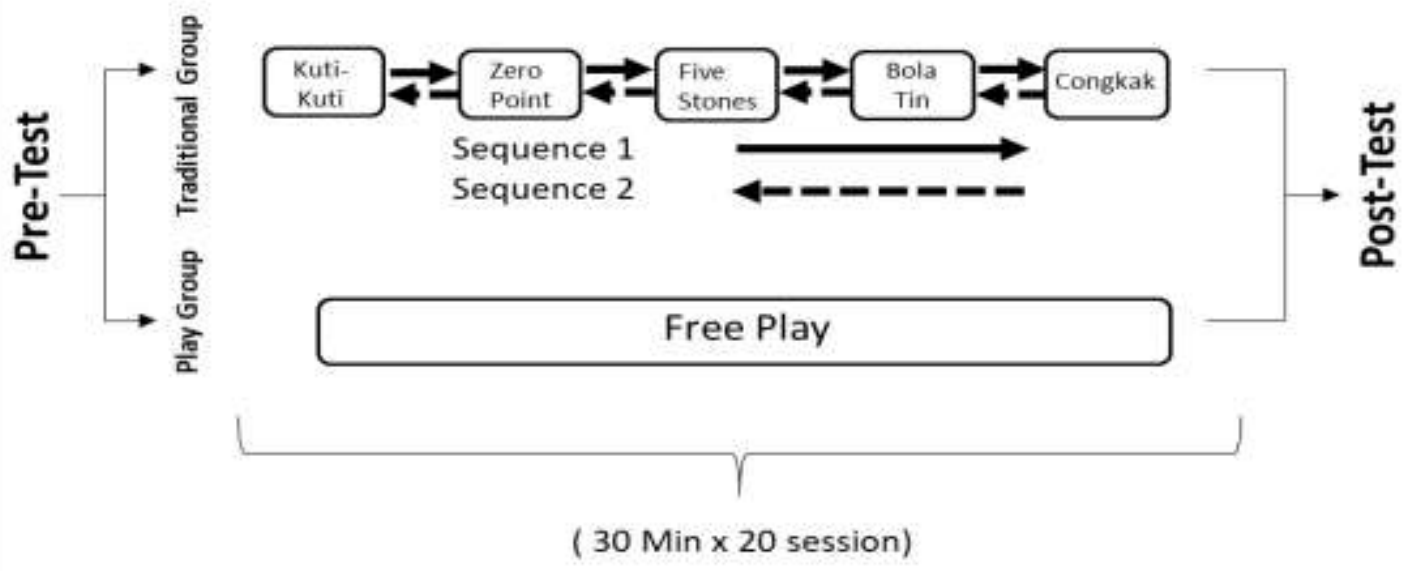

Figure 1. Systematic Flow Chart of the intervention sequence of Traditional Group and Play Group 
International Journal of Childhood, Counselling, \& Special Education (CCSE), Volume1, Issue: 2, December: 2020, pp.204-223

Traditional Group. The Traditional Group were taught how to play five types of traditional games played in Singapore. Children played the games twice a week for 30 minutes per session, spanning over a fiveweek period. In every session, the intervention was carried out for individual play followed by peer play in a fixed sequential rotation with a different game at each session. There were two sequences to ease the possibility of novelty and recency effects (see Figure 1). The Traditional Group were randomly spilt either into sequence 1 or sequence 2 for the 20 sessions of structured traditional game play. The children played four consecutive sessions of one game before proceeding to the next game. The descriptions of each traditional game were as mentioned below.

Bola Tin. Individual Play: Player has to knock down as many tins as possible over a distance of one-metre within five continuous tries. Peer Play: Players play against each other to knock down as many tins as possible over a distance of one-metre within five alternate tries.

Congkak. Individual Play: Player has to take and drop as many 'seeds' as possible from small holes into big holes (home) within three minutes. Peer Play: Players play against each other to take and drop as many 'seeds' as possible from small holes into big holes (home) within three minutes.
Five Stones (Batu Serembat). Individual Play: Player has to throw and catch the 'stones' up in the air within five continuous tries. Peer Play: Players play against each other to throw and catch the 'stones' with each other within five alternate tries. Zero Point (Ye-Ye). Individual Play: Player has to complete four-step jump sequence with various level of difficulty. Peer Play: Players play against each other to complete fourstep jump sequence with various level of difficulty simultaneously.

Kuti-Kuti. Individual Play: Player has to aim and hit as many Kuti-Kuti as possible out of the boundary within five continuous tries. Peer Play: Players play against each other to aim and hit as many Kuti-Kuti as possible out of the boundary within five alternate tries.

Play Group. The Play Group went through unstructured free play in an indoor environment during the 20session period. A free play refers to unstructured and child-initiated activities where children were free to explore their imagination during play. Children in the Play Group participated in a variety of activities such as block play, dough play, kitchen play and art \& craft.

Test Procedures and Instructions:

All tests and intervention sessions were conducted in a supervised indoor environment within the participants' kindergarten compounds. Standardised verbal 
International Journal of Childhood, Counselling, \& Special Education (CCSE), Volume1, Issue: 2, December: 2020, pp.204-223

instructions and visual demonstrations were conducted in accordance to the MABC-2 guidelines during all test sessions by testers who met the minimum interand intra-reliability index $(r \geq 0.7)$. The sequence for data collection procedures were pre-test, 20 sessions of intervention (either traditional games or free play) followed by posttest for both traditional and play groups.

Data Reduction and Analysis:

The raw scores (RS) of every task were converted to standard scores (SS) and component scores (TSSMD, TSSAC, TSSBAL \& TSS) with reference to the MABC-2 normative sample tables. The SS refers to the relative results against the MABC-2 normative sample data. Higher SS represents better motor skills in terms of MABC-2 task items. The mixed MANOVA and ANOVA with post-hoc tests using unpaired t-test and paired $t$-test were used to find for significant differences at $p<.05$. Results were presented for 1) All Participants; 2) Performing 30 - with highest overall TSS pre-test scores and 3) Underperforming 30 - with lowest overall TSS pre-test scores for each group (traditional group \& play group). The conventional effect size values used to determine the magnitude of the significant differences were: small $\left(\eta^{2}=0.01\right)$, medium $\left(\eta^{2}=0.06\right)$, large $\left(\eta^{2}=0.14\right.$; Cohen, 1988).

\section{Results}

All Participants:

The MANOVA, ANOVA, unpaired $t$-test and paired $t$-test were used to test for significant differences between groups (traditional group: $n$ $=114$, play group: $n=78$ ) based on their standard scores (RS \& SS) for all MABC-2 test items (see Table 1). The MANOVA results showed nonsignificant differences between subjects (Traditional Group: $n=114$ vs Play Group: $n=78$; SS: F $(4,187)$ $=1.134, p=.342$, Pillai's Trace $=.024$, $\left.\eta^{2}=.024\right)$. Nonetheless, interpretation of the data within subjects (pre vs post) showed significant differences (SS: F $(4,187)$ $=5.928, p=.000$, Pillai's Trace $=$ $\left.0.113, \eta^{2}=0.113\right)$. Overall, there was a non-significant interaction effect (SS: $F(4,187)=0.677, p=.609$, Pillai's Trace $=0.014, \eta^{2}=0.014$ ).

Further analysis using ANOVA showed significant improvements within subjects with small effect size in both groups for TSSAC, TSSBAL and TSS $(p<.05$; see Table 1$)$. Posthoc paired $t$-test results revealed that significant improvements were still evident in each of the two groups for TSSBAL and TSS ( $p<.05$; see Table 2). 
International Journal of Childhood, Counselling, \& Special Education (CCSE), Volume1, Issue: 2, December: 2020, pp.204-223

Table 1: ANOVA results of within and between groups of All Participants (Traditional group: $n=$ 114 ES Play group: $n=78$ )

\begin{tabular}{|c|c|c|c|c|c|}
\hline $\begin{array}{l}\text { All } \\
\text { Participants }\end{array}$ & $\begin{array}{l}\underline{P R E} \\
\mathrm{M} \\
(\mathrm{SD})\end{array}$ & $\begin{array}{l}\text { POST } \\
\text { M } \\
\text { (SD) }\end{array}$ & $\begin{array}{l}\frac{\text { Within }}{\text { Subjects }} \\
\text { F } \\
\text { (p) } \eta^{2}\end{array}$ & $\begin{array}{l}\frac{\text { Between }}{\text { Subjects }} \\
\text { F } \\
\text { (p) } \eta^{2}\end{array}$ & $\begin{array}{l}\frac{\text { Interaction }}{(\text { Test \& Grp) }} \\
\text { F } \\
(p) \eta^{2}\end{array}$ \\
\hline TSSMD & $\begin{array}{l}10.16 \\
(2.487)\end{array}$ & $\begin{array}{l}10.40 \\
(2.304)\end{array}$ & $\begin{array}{l}0.948 \\
(.331) 0.005\end{array}$ & $\begin{array}{l}2.297 \\
(.131) 0.012\end{array}$ & $\begin{array}{l}1.074 \\
(.301) 0.006\end{array}$ \\
\hline TSSAC & $\begin{array}{l}8.271 \\
(2.570)\end{array}$ & $\begin{array}{l}8.724 \\
(2.591)\end{array}$ & $\begin{array}{l}4.843 \\
\left(.029^{*}\right) 0.025\end{array}$ & $\begin{array}{l}0.051 \\
(.821) 0.000\end{array}$ & $\begin{array}{l}0.983 \\
.323) 0.005\end{array}$ \\
\hline TSSBAL & $\begin{array}{l}12.05 \\
(3.515)\end{array}$ & $\begin{array}{l}13.16 \\
(3.135)\end{array}$ & $\begin{array}{l}20.46 \\
\left(.000^{*}\right) 0.097\end{array}$ & $\begin{array}{l}2.277 \\
0.133) 0.012\end{array}$ & $\begin{array}{l}0.019 \\
(.890) 0.000\end{array}$ \\
\hline TSS overall & $\begin{array}{l}10.10 \\
(2.654)\end{array}$ & $\begin{array}{l}10.85 \\
(2.435)\end{array}$ & $\begin{array}{l}15.05 \\
\left(.000^{*}\right) 0.073\end{array}$ & $\begin{array}{l}1.813 \\
(.180) 0.009\end{array}$ & $\begin{array}{l}0.001 \\
(.978) 0.000\end{array}$ \\
\hline
\end{tabular}

Table 2: Unpaired and paired t-test results of within and between groups of All Participants (Traditional Group: $n=114$ EB Play Group: $n=78$ )

\begin{tabular}{|c|c|c|c|c|c|c|c|c|}
\hline \multirow{3}{*}{$\begin{array}{l}\text { All } \\
\underline{\text { Participants }}\end{array}$} & \multicolumn{2}{|c|}{$\underline{\text { Play Group }}$} & \multicolumn{2}{|c|}{$\underline{\text { Traditional Group }}$} & \multirow{2}{*}{\multicolumn{2}{|c|}{$\begin{array}{l}\text { Unpaired } t \\
\mathrm{~T} \text { (p value) }\end{array}$}} & \multirow{2}{*}{\multicolumn{2}{|c|}{$\begin{array}{l}\text { Paired } t \\
\underline{T(p \text { value })}\end{array}$}} \\
\hline & \multirow{2}{*}{$\begin{array}{l}\frac{\mathrm{PRE}}{\mathrm{M}} \\
(\mathrm{SD})\end{array}$} & \multirow{2}{*}{$\begin{array}{l}\frac{\text { POST }}{\mathrm{M}} \\
\text { (SD) }\end{array}$} & \multirow{2}{*}{$\begin{array}{l}\frac{\mathrm{PRE}}{\mathrm{M}} \\
(\mathrm{SD})\end{array}$} & \multirow{2}{*}{$\begin{array}{l}\frac{\text { POST }}{M} \\
\text { (SD) }\end{array}$} & & & & \\
\hline & & & & & Pre-test & Post-test & $\begin{array}{l}\text { Play } \\
\text { Group }\end{array}$ & $\begin{array}{l}\text { Traditional } \\
\text { Group }\end{array}$ \\
\hline TSSMD & $\begin{array}{l}10.03 \\
(2.279)\end{array}$ & $\begin{array}{l}10.01 \\
(2.117)\end{array}$ & $\begin{array}{l}10.25 \\
(2.626)\end{array}$ & $\begin{array}{l}10.66 \\
(2.398)\end{array}$ & $\begin{array}{l}0.617 \\
(.538)\end{array}$ & $\begin{array}{l}1.964 \\
(.051)\end{array}$ & $\begin{array}{l}0.042 \\
(.966)\end{array}$ & $\begin{array}{l}1.536 \\
(.127)\end{array}$ \\
\hline TSSAC & $\begin{array}{l}8.18 \\
(2.662)\end{array}$ & $\begin{array}{l}8.897 \\
(2.656)\end{array}$ & $\begin{array}{l}8.333 \\
(2.516)\end{array}$ & $\begin{array}{l}8.605 \\
(2.551)\end{array}$ & $\begin{array}{l}0.402 \\
(.688)\end{array}$ & $\begin{array}{l}0.761 \\
(.448)\end{array}$ & $\begin{array}{l}1.839 \\
(.070)\end{array}$ & $\begin{array}{l}1.050 \\
(.296)\end{array}$ \\
\hline TSSBAL & $\begin{array}{l}11.69 \\
(3.774)\end{array}$ & $\begin{array}{l}12.76 \\
(3.063)\end{array}$ & $\begin{array}{l}12.30 \\
(3.320)\end{array}$ & $\begin{array}{l}13.43 \\
(3.168)\end{array}$ & $\begin{array}{l}1.147 \\
(.253)\end{array}$ & $\begin{array}{l}1.475 \\
(.142)\end{array}$ & $\begin{array}{l}2.474 \\
\left(.016^{*}\right)\end{array}$ & $\begin{array}{l}4.139 \\
\left(.000^{*}\right)\end{array}$ \\
\hline TSS overall & $\begin{array}{l}9.85 \\
(2.754)\end{array}$ & $\begin{array}{l}10.59 \\
(2.224)\end{array}$ & $\begin{array}{l}10.27 \\
(2.581)\end{array}$ & $\begin{array}{l}11.03 \\
(2.564)\end{array}$ & $\begin{array}{l}1.079 \\
(.282)\end{array}$ & $\begin{array}{l}1.255 \\
(.211)\end{array}$ & $\begin{array}{l}2.196 \\
\left(.031^{*}\right)\end{array}$ & $\begin{array}{l}3.430 \\
\left(.001^{*}\right)\end{array}$ \\
\hline (*) Denotes sig & icant diffe & ces at $p<$ & & & & & & \\
\hline
\end{tabular}

Performing 30:

This section illustrated the first 30 participating children of each group with the highest overall TSS pre-test results. Repeated MANOVA, ANOVA, unpaired t-test and paired $t$-test was used to analyse the Performing 30 of each group $(n=$ 60; 30 children from Traditional Group \& 30 children from Play Group). From the MANOVA results, significant differences were seen between subjects $(\mathrm{SS}: \mathrm{F}(4,55)=$ 3.552, $p=.012$, Pillai's Trace $=.205$, $\eta^{2}=.205$; see Table 3). There were non-significant differences within subjects (SS: $F(4,55)=1.518, p=$ .210, Pillai's Trace $=0.099, \quad \eta^{2}=$ 0.099). In addition, there was nonsignificant interaction effect (SS: F $(4,55)=0.660, p=.623$, Pillai's Trace $\left.=0.046, \eta^{2}=0.046\right)$. 
International Journal of Childhood, Counselling, \& Special Education (CCSE), Volume1, Issue: 2, December: 2020, pp.204-223

Follow-up ANOVA results further revealed significant differences between subjects with small effect size for TSSMD and TSS $(p<.05$; see Table 3$)$. Non-significant results were seen within subjects and interaction effect ( $p>.05$; see Table 3). Post-hoc unpaired t-test showed that the Traditional Group performed significantly better with a higher mean value for TSSMD and TSS than the Play Group $(p<.05$; see Table 4). However, non-significant paired t-test difference was observed between Traditional Group and Play Group ( $p>.05$; see Table 3).

Table 3: ANOVA results of within and between groups of Performing 30 category (Traditional group: $n=30 ;$ Play group: $n=30$ )

\begin{tabular}{|c|c|c|c|c|c|}
\hline $\begin{array}{l}\text { PERFORMING } \\
\underline{30}\end{array}$ & $\begin{array}{l}\text { PRE } \\
\text { M } \\
(\mathrm{SD})\end{array}$ & $\begin{array}{l}\text { M } \\
\text { (SD) }\end{array}$ & $\begin{array}{l}\frac{\text { Within }}{\text { Subjects }} \\
\text { F } \\
\text { (p) } \eta^{2}\end{array}$ & $\underline{\text { Between Subjects }}$ & $\begin{array}{l}\frac{\text { Interaction }}{(\text { Test \& Grp) }} \\
\text { F } \\
\text { (p) } \eta^{2}\end{array}$ \\
\hline TSSMD & $\begin{array}{l}12.07 \\
(1.656)\end{array}$ & $\begin{array}{l}11.65 \\
(2.130)\end{array}$ & $\begin{array}{l}.813 \\
(.183) 0.030\end{array}$ & $\begin{array}{l}7.885 \\
\left(.007^{*}\right) 0.120\end{array}$ & $\begin{array}{l}1.279 \\
(.263) 0.022\end{array}$ \\
\hline TSSAC & $\begin{array}{l}10.05 \\
(2.411)\end{array}$ & $\begin{array}{l}9.83 \\
(2.109)\end{array}$ & $\begin{array}{l}0.298 \\
(.587) 0.005\end{array}$ & $\begin{array}{l}0.787 \\
(.379) 0.013\end{array}$ & $\begin{array}{l}0.510 \\
(.478) 0.009\end{array}$ \\
\hline TSSBAL & $\begin{array}{l}14.95 \\
(2.174)\end{array}$ & $\begin{array}{l}14.77 \\
(2.375)\end{array}$ & $\begin{array}{l}0.262 \\
(.611) 0.004\end{array}$ & $\begin{array}{l}1.396 \\
(.242) 0.024\end{array}$ & $\begin{array}{l}0.486 \\
(.488) 0.008\end{array}$ \\
\hline TSS overall & $\begin{array}{l}12.80 \\
(1.494)\end{array}$ & $\begin{array}{l}12.52 \\
(2.063)\end{array}$ & $\begin{array}{l}0.679 \\
(.413) 0.012\end{array}$ & $\begin{array}{l}11.73 \\
\left(.001^{*}\right) 0.168\end{array}$ & $\begin{array}{l}1.243 \\
(.269) 0.021\end{array}$ \\
\hline
\end{tabular}

Table 4: Unpaired and paired t-test results of within and between groups of Performing 30 category

(Traditional group: $n=30$; Play group: $n=30$ )

\begin{tabular}{|c|c|c|c|c|c|c|c|c|}
\hline \multirow{3}{*}{$\begin{array}{l}\text { PERFORMING } \\
\underline{30}\end{array}$} & \multicolumn{2}{|c|}{ Play Group } & \multicolumn{2}{|c|}{$\underline{\text { Traditional Group }}$} & \multirow{2}{*}{\multicolumn{2}{|c|}{$\frac{\text { Unpaired } t}{\mathrm{~T} \text { (p value) }}$}} & \multirow{2}{*}{\multicolumn{2}{|c|}{$\frac{\text { Paired } t}{\mathrm{~T} \text { (pvalue })}$}} \\
\hline & \multirow{2}{*}{$\begin{array}{l}\frac{P R E}{M} \\
\text { (SD) }\end{array}$} & \multirow{2}{*}{$\begin{array}{l}\frac{\text { POST }}{\mathrm{M}} \\
\text { (SD) }\end{array}$} & \multirow{2}{*}{$\begin{array}{l}\frac{\mathrm{PRE}}{\mathrm{M}} \\
(\mathrm{SD})\end{array}$} & \multirow{2}{*}{$\begin{array}{l}\frac{\text { POST }}{\mathrm{M}} \\
(\mathrm{SD})\end{array}$} & & & & \\
\hline & & & & & Pre-test & Post-test & $\begin{array}{l}\text { Play } \\
\text { Group }\end{array}$ & $\begin{array}{l}\text { Traditional } \\
\text { Group }\end{array}$ \\
\hline TSSMD & $\begin{array}{l}11.73 \\
(1.507)\end{array}$ & $\begin{array}{l}10.97 \\
(1.884)\end{array}$ & $\begin{array}{l}12.40 \\
(1.754)\end{array}$ & $\begin{array}{l}12.33 \\
(2.171)\end{array}$ & $\begin{array}{l}-0.158 \\
(.120)\end{array}$ & $\begin{array}{l}-2.604 \\
\left(.012^{*}\right)\end{array}$ & $\begin{array}{l}1.727 \\
(.095)\end{array}$ & $\begin{array}{l}0.155 \\
(.878)\end{array}$ \\
\hline TSSAC & $\begin{array}{l}10.00 \\
(2.600)\end{array}$ & $\begin{array}{l}9.500 \\
(2.360)\end{array}$ & $\begin{array}{l}10.10 \\
(2.249)\end{array}$ & $\begin{array}{l}10.17 \\
(1.802)\end{array}$ & $\begin{array}{l}0.159 \\
(.874)\end{array}$ & $\begin{array}{l}-1.230 \\
(.224)\end{array}$ & $\begin{array}{l}0.757 \\
(.455)\end{array}$ & $\begin{array}{l}-0.152 \\
(.880)\end{array}$ \\
\hline TSSBAL & $\begin{array}{l}14.80 \\
(2.384)\end{array}$ & $\begin{array}{l}14.37 \\
(2.593)\end{array}$ & $\begin{array}{l}15.10 \\
(1.971)\end{array}$ & $\begin{array}{l}15.17 \\
(2.102)\end{array}$ & $\begin{array}{l}-0.531 \\
(.597)\end{array}$ & $\begin{array}{l}-1.313 \\
(.195)\end{array}$ & $\begin{array}{l}0.830 \\
(.414)\end{array}$ & $\begin{array}{l}-0.136 \\
(.893)\end{array}$ \\
\hline TSS overall & $\begin{array}{l}12.50 \\
(1.717)\end{array}$ & $\begin{array}{l}11.83 \\
(1.984)\end{array}$ & $\begin{array}{l}13.10 \\
(1.185)\end{array}$ & $\begin{array}{l}13.20 \\
(1.937)\end{array}$ & $\begin{array}{r}-1.575 \\
(.121)\end{array}$ & $\begin{array}{l}-2.700 \\
\left(.009^{*}\right)\end{array}$ & $\begin{array}{l}1.268 \\
(.215)\end{array}$ & $\begin{array}{l}-0.226 \\
(.823)\end{array}$ \\
\hline Denot & $t$ differen & $t p<.05$ & & & & & & \\
\hline
\end{tabular}

Underperforming 30:

This section illustrated the last 30 participating children of each group with the lowest overall TSS pre-test results. Repeated
MANOVA, ANOVA, unpaired t-test and paired $t$-test was used to analyse the Underperforming 30 of each group $(n=60 ; 30$ children from 
International Journal of Childhood, Counselling, \& Special Education (CCSE), Volume1, Issue: 2, December: 2020, pp.204-223

Traditional Group \& 30 children from Play Group). From the MANOVA results, non-significant differences were seen between subjects (SS: $F(4,55)=.707, p=.590$, Pillai's Trace $=.049, \eta^{2}=.049$ ). Significance differences were seen within subjects (SS: $\mathrm{F}(4,55)=$ $15.762, p=.000$, Pillai's Trace $=.534$, $\left.\eta^{2}=.534\right)$. In terms of interaction effect, non-significant result was observed (SS: F $(4,55)=0.952, p$ $=.441$, Pillai's Trace $=0.065, \eta^{2}=$ $0.065)$.
Follow up ANOVA results reported non-significant differences between subjects $(p>.05$; see Table 5). Significant differences were observed within subjects for all tasks with small effect size $(p<.05$; see Table 5). Non-significant interaction effect was observed ( $p>.05$; see Table 6). Post-hoc unpaired t-test showed non-significant differences for both pre-test and post-test $(p>.05$; see Table 6). Paired t-test had showed significant improvement in fewer tasks for the Traditional Group than the Play Group ( $p<.05$; see Table 6 ).

Table 5: ANOVA results of within and between groups of Underperforming 30 category (Traditional group: $n=30$; Play group: $n=30$ )

\begin{tabular}{|c|c|c|c|c|c|}
\hline $\begin{array}{l}\text { UNDER } \\
\text { PERFORMING } 30 \\
\end{array}$ & $\begin{array}{l}\text { PRE } \\
\text { M } \\
\text { (SD) }\end{array}$ & $\begin{array}{l}\text { POST } \\
\text { M } \\
\text { (SD) } \\
\end{array}$ & $\begin{array}{l}\text { Within } \\
\text { Subjects } \\
\text { F } \\
(p) \eta^{2}\end{array}$ & $\begin{array}{l}\underline{\text { Between }} \\
\text { Subjects } \\
\mathrm{F} \\
(p) \eta^{2}\end{array}$ & $\begin{array}{l}\text { Interaction } \\
\text { (Test \& Grp) } \\
\text { F } \\
(p) \eta^{2}\end{array}$ \\
\hline TSSMD & $\begin{array}{l}7.967 \\
(2.115)\end{array}$ & $\begin{array}{l}9.450 \\
(2.281)\end{array}$ & $\begin{array}{l}14.74 \\
\left(.000^{*}\right) 0.203\end{array}$ & $\begin{array}{l}1.537 \\
(.220) 0.026\end{array}$ & $\begin{array}{l}0.151 \\
(.699) 0.003\end{array}$ \\
\hline TSSAC & $\begin{array}{l}6.567 \\
(2.302)\end{array}$ & $\begin{array}{l}7.617 \\
(2.738)\end{array}$ & $\begin{array}{l}8.997 \\
\left(.004^{*}\right) 0.134\end{array}$ & $\begin{array}{l}0.671 \\
(.416) 0.011\end{array}$ & $\begin{array}{l}2.777 \\
(.101) 0.046\end{array}$ \\
\hline TSSBAL & $\begin{array}{l}8.650 \\
(2.557)\end{array}$ & $\begin{array}{l}11.37 \\
(3.221)\end{array}$ & $\begin{array}{l}48.85 \\
\left(.000^{*}\right) 0.457\end{array}$ & $\begin{array}{l}0.112 \\
(.739) 0.002\end{array}$ & $\begin{array}{l}1.149 \\
(.288) 0.019\end{array}$ \\
\hline TSS overall & $\begin{array}{l}7.133 \\
(1.702)\end{array}$ & $\begin{array}{l}9.350 \\
(2.441)\end{array}$ & $\begin{array}{l}51.60 \\
\left(.000^{*}\right) 0.471\end{array}$ & $\begin{array}{l}0.608 \\
(.439) 0.010\end{array}$ & $\begin{array}{l}0.843 \\
(.362) 0.014\end{array}$ \\
\hline
\end{tabular}

Table 6: Unpaired and paired t-test results of within and between groups of Underperforming 30 category (Traditional group: $n=30$; Play group: $n=30$ )

\begin{tabular}{|c|c|c|c|c|c|c|c|c|}
\hline \multirow{3}{*}{$\begin{array}{l}\text { UNDER } \\
\text { PERFORMING } 30 \\
\end{array}$} & \multicolumn{2}{|c|}{ Play Group } & \multicolumn{2}{|c|}{ Traditional Group } & \multirow{2}{*}{\multicolumn{2}{|c|}{$\begin{array}{l}\text { Unpaired } t \\
\underline{\mathrm{T} \text { ( } p \text { value })}\end{array}$}} & \multirow{2}{*}{\multicolumn{2}{|c|}{$\begin{array}{c}\underline{\text { Paired } t} \\
\underline{\mathrm{T} \text { ( } p \text { value })}\end{array}$}} \\
\hline & \multirow{2}{*}{$\begin{array}{l}\underline{P R E} \\
M \\
\text { (SD) }\end{array}$} & \multirow{2}{*}{$\begin{array}{l}\text { POST } \\
\mathrm{M} \\
(\mathrm{SD})\end{array}$} & \multirow{2}{*}{$\begin{array}{l}\underline{\text { PRE }} \\
\mathrm{M} \\
(\mathrm{SD})\end{array}$} & \multirow{2}{*}{$\begin{array}{l}\text { POST } \\
M \\
(\mathrm{SD})\end{array}$} & & & & \\
\hline & & & & & Pre-test & Post-test & $\begin{array}{l}\text { Play } \\
\text { Group }\end{array}$ & $\begin{array}{l}\text { Traditional } \\
\text { Group }\end{array}$ \\
\hline TSSMD & $\begin{array}{l}8.300 \\
(1.745)\end{array}$ & $\begin{array}{l}9.633 \\
(2.008)\end{array}$ & $\begin{array}{l}7.633 \\
(2.414)\end{array}$ & $\begin{array}{l}9.267 \\
(2.545)\end{array}$ & $\begin{array}{l}1.226 \\
(.226)\end{array}$ & $\begin{array}{l}0.619 \\
(.538)\end{array}$ & $\begin{array}{l}-2.976 \\
\left(.006^{*}\right)\end{array}$ & $\begin{array}{l}2.594 \\
\left(.015^{*}\right)\end{array}$ \\
\hline TSSAC & $\begin{array}{l}6.500 \\
(2.047)\end{array}$ & $\begin{array}{l}8.133 \\
(2.675)\end{array}$ & $\begin{array}{l}6.633 \\
(2.566)\end{array}$ & $\begin{array}{l}7.100 \\
(2.746)\end{array}$ & $\begin{array}{l}-0.222 \\
(.825)\end{array}$ & $\begin{array}{l}1.476 \\
(.145)\end{array}$ & $\begin{array}{l}-3.301 \\
\left(.003^{*}\right)\end{array}$ & $-0.942(.354)$ \\
\hline TSSBAL & $\begin{array}{l}8.333 \\
(2.631)\end{array}$ & $\begin{array}{l}11.47 \\
(2.675)\end{array}$ & $\begin{array}{l}8.967 \\
(2.484)\end{array}$ & $\begin{array}{l}11.27 \\
(3.732)\end{array}$ & $\begin{array}{l}-0.959 \\
(.342)\end{array}$ & $\begin{array}{l}0.239 \\
(.812)\end{array}$ & $\begin{array}{l}-5.254 \\
\left(.000^{*}\right)\end{array}$ & $-4.613\left(.000^{*}\right)$ \\
\hline TSS OVERALL & $\begin{array}{l}7.167 \\
(1.464)\end{array}$ & $\begin{array}{l}9.667 \\
(1.688)\end{array}$ & $\begin{array}{l}7.100 \\
(1.936)\end{array}$ & $\begin{array}{l}9.033 \\
(3.011)\end{array}$ & $\begin{array}{l}0.150 \\
(.881)\end{array}$ & $\begin{array}{l}1.005 \\
(.320)\end{array}$ & $\begin{array}{l}-2.976 \\
\left(.000^{*}\right)\end{array}$ & $-3.918\left(.000^{*}\right)$ \\
\hline$\left({ }^{*}\right)$ Denotes signif & it differe & at $p<.0$ & & & & & & \\
\hline
\end{tabular}


International Journal of Childhood, Counselling, \& Special Education (CCSE), Volume1, Issue: 2, December: 2020, pp.204-223

\section{Discussion}

To our knowledge, this study appears to be the first to investigate the effect of traditional games and free play for motor skill development in preschool children aged three to six years old. This study aimed to find out how preschool children's motor skills would develop under different forms of child's physical play - structured traditional games (i.e. Traditional Group) and unstructured free play (i.e. Play Group). The findings in this study observed that both structured (Traditional Group) and unstructured play (Play Group) would improve the motor skills in preschool children (see Table $1 \& 2$ ). Both groups of children made significant improvement in their balance skills (TSSBAL) and overall motor skills (TSS). Although the literature appears limited to include unstructured play when making comparisons between the different forms of physical play (Deli et al., 2006; Hamilton \& Liu, 2018), interestingly, this study has shown contentious but tangible benefits with the significant improvement made by the Play Group who engaged in free play activities. Nonetheless, the significantly improved overall motor scores of the Traditional Group in this study aligned with other intervention studies (Abdullah et al., 2013; Akbari et al., 2009).
Limited studies have been done to evaluate the effectiveness of intervention programmes on the children with different motor skills proficiencies. In this study, besides evaluating the participants based on Traditional Group $(n=114)$ or Play Group $(n=78)$, each group were further categorised as the best 30 and the worst 30 (namely Performing 30 \& Underperforming 30) respectively. The findings in this study suggested that regardless of being in the Play Group or Traditional Group, the Underperforming 30 experienced more significant benefits than their Performing 30 peers (see Table $4 \&$ 6). Both Traditional Group and Play Group categorised under the Underperforming 30 made significant pre-post improvement in their manual dexterity (TSSMD), aiming and catching (TSSAC), balance (TSSBAL) and overall motor scores (TSS) while no significant prepost improvement was seen for both groups under the Performing 30. This finding aligned with other studies by Akbari et al. (2009) and Abdullah et al. (2013), where participants with below-norm motor proficiencies exhibited significant improvement after the intervention of playing traditional games. However, going through structured flow of traditional games seem to be better than having free play which was demonstrated by the participants who started off with better motor 
International Journal of Childhood, Counselling, \& Special Education (CCSE), Volume1, Issue: 2, December: 2020, pp.204-223

proficiencies. Within the Performing 30 category, the Traditional Group performed significantly better than the Play Group at post-test in terms of manual dexterity (TSSMD) and overall motor skills (TSS) although they started off with non-significant baseline differences (see Table 4). The improved manual dexterity in the Traditional Group could be explained with the frequently played traditional games such as Batu Serembat, Kuti Kuti and Congkak in which these tasks required upper limb and fine finger movements.

Our findings also corroborated with the other studies (Akbari et al., 2009; Ghipit@ Charles et al., 2017; Jaydari et al., 2016) where traditional games did not improve all motor skills. Descriptive statistics of present study suggested that there were improved scores in terms of manual dexterity skills (TSSMD), aiming and catching (TSSAC), balance skills (TSSBAL) and overall motor skills (TSS) as seen from the Traditional Group while similar improvements could also be observed in the Play Group with the exception of the TSSMD. These results can be further substantiated by Newell's (1986) ecological perspective of motor development. Any forms of environmental influences are likely to affect motor skill development which could be observed as the significant improvements experienced by both Traditional Group and Play Group. Based on the findings of this study, one could infer that children would continue to develop and improve their motor skills regardless of the types of interventions so long as the programmes were intended to be environmental aid to promote physical play. Specifically, the results of this study further indicated a clearer positive effect on children with poorer motor skills proficiency in the Underperforming 30 category.

Abdullah et al. (2013) reported that there were significant improvements in all motor skill tasks. In their study, traditional games group performed significantly better than the control group for all tasks at post-test (Abdullah et al., 2013). Direct comparison to our study cannot be done due to the different task category. The current study had no significant differences between Traditional Group and Play Group at both pre-test and post-test. The disparity of results between studies could then be due to the nature of motor assessment. Abdullah (2013) used TGMD-2 (Ulrich, 2000) which is a processoriented motor assessment while our study used MABC-2 (Henderson et al., 2007) which is a product-oriented motor assessment. The TGMD-2 and MABC-2 evaluate similar skills in dissimilar ways. This was also highlighted in Logan et al.'s (2014) study of the possibility that performance scores of the same participants would be poorer on 
International Journal of Childhood, Counselling, \& Special Education (CCSE), Volume1, Issue: 2, December: 2020, pp.204-223

TGMD-2 as compared to MABC-2. The authors further added that MABC-2 might be easier to have consistently better scores while TGMD-2 would be more suitable for classifying children. Since the current study used MABC-2, the participants in both groups may find it easy to fulfil outcome-based requirement and tend to perform consistently well which thus could be the reason for non-significant differences between subjects in this current study.

Most traditional games are derived from the native country's culture and thus demonstrated the country's identity. Among all motor invention studies that used traditional games, the findings on their effectiveness were inconsistent as the traditional games were played differently. Some studies had more significant improvements in certain tasks. The current study demonstrated that both Traditional Group and Play Group had significant improvements such that the Traditional Group had the capability of having significantly better motor skills than the Play Group after traditional game play rather than free play $(p<.05)$.

It is recommended that future studies could examine the impact of different traditional games on motor skills. This might offer better awareness of the potential effects of the different types of traditional games on motor skill development.
Each traditional game focuses on different learning outcomes which might likely target at different motor skill development. However, since the Traditional Group generally performed significantly better from the baseline performance at the end of intervention as well as when compared to the Play Group under the Performing 30 category, further investigation to identify which traditional games could elicit most improvement is warranted. We suggest that future research could create a pure experimental design where the intervention group should have additional traditional game sessions, on top of their usual unstructured play time spent in preschools or childcare centres. The control group would then be those children who had their usual unstructured play time spent in preschools or childcare centres during the intervention period.

In conclusion, the findings of this study implied that having any form of play, structured traditional games or unstructured free play, would help to improve the motor skills of preschool children. In this study, preschool children who were not performing well in their motor skills made better gains especially in tasks that required manual dexterity skills. However, preschool children who started off with better motor skills, showed more promising improvements with structured traditional games rather than 
International Journal of Childhood, Counselling, \& Special Education (CCSE), Volume1, Issue: 2, December: 2020, pp.204-223

unstructured free play. Nonetheless, this study provided an insight to structured traditional game activities as part of a physical activity programme for children.

\section{References}

Abdullah, B., Amri, S., Kok, L., \& Samah, B. A. (2013). The Impact of Traditional Games on the Gross Motor Skill Development of an Early Childhood. The Social Sciences Medwell Journals, 8(6), 590-595.

Akbari, H., Abdoli, B., Shafizadeh, M., Khalaji, H., Hajihosseini, S., \& Ziaee, V. (2009). The Effect of Traditional Games in Fundamental Motor Skill Development in 7-9. Year-Old Boys. Iranian Journal of Pediatrics, 19(2), 123-129.

Barreiro, J., \& Howard, R. (2017). Incorporating Unstructured Free Play into Organized Sports. Strength and Conditioning Journal, 39(2), 11-19.

https://doi.org/10.1519/ssc.0000000000 000291

Bremer, E., Balogh, R., \& Lloyd, M. (2015). Effectiveness of a fundamental motor skill intervention for 4-year-old children with autism spectrum disorder: A pilot study. Autism, 19(8), 980-991. https://doi.org/10.1177/1362361314557 548

Cohen, J. (1988). Statistical Power Analysis for the Behavioral Sciences. New York, US: Routledge Academic.
Deli, E., Bakle, I., \& Zachopoulou, E. (2006). Implementing intervention movement programs for kindergarten children. Journal of Early Childhood Research, 4(1), 518.

https://doi.org/10.1177/1476718x06059 785

Dockett, S. (1999). Thinking about play, playing about thinking. In E. Dau (Ed.). Child's play: revisiting play in early childhood settings (pp. 28-46). Sydney, AZ: MacLennan and Petty.

Faigenbaum, A., Lloyd, R. \& Myer, G. (2013). Youth resistance training: past practices, new perspectives, and future directions. Pediatric Exercise Science, 25(4), 591-604. https://doi.org/10.1123/pes.25.4.591

Fisher, A., Reilly, J. J., Kelly, L. A., Montgomery, C., Williamson, A., Paton, J. Y., \& Grant, S. (2005). Fundamental movement skills and habitual physical activity in young children. Medicine \& Science in Sports \& Exercise, 37(4), 684-88.

Fleer, M. (2015). Play in the Early Years. Cambridge, UK: University Press.

Ghipit@ Charles, M. A., Abdullah, M. R., Musa, R. M., Kosni, N. A., \& Maliki, A. B. H. M. (2017). The effect of traditional games intervention programme in the enhancement school-age children's motor skills: A preliminary study, Health, Movement \& Exercise, 6(2), 
International Journal of Childhood, Counselling, \& Special Education (CCSE), Volume1, Issue: 2, December: 2020, pp.204-223

157-169.

https://doi.org/10.15282/mohe.v6i2.142

Gonchu, A. \& Gaskins, S. (2011). Comparing and extending Piaget's and Vygotsky's understandings of play: symbolic play as individual, sociocultural, and educational interpretations, In A.D. Pellegrini (Ed.). The Oxford handbook of development of play (pp. 48-57). Oxford, UK: Oxford University Press.

Goodway, J. D. \& Branta, C. F. (2003). Influence of a Motor Skill Intervention on Fundamental Motor Skill Development of Disadvantaged Preschool Children, Research Quarterly for Exercise and Sport, 74(1), 36-46.

https://doi.org/10.1080/02701367.2003. 10609062

Goodway, J. D., Crowe, H., \& P. Ward. (2003). Effects of Motor Skill Instruction on Fundamental Motor Skill Development, Adapted Physical Activity Quarterly, 20(3), 298-314. https://doi.org/10.1123/apaq.20.3.298

Hamilton, M., \& Liu, T. (2018). The Effects of an Intervention on the Gross and Fine Motor Skills of Hispanic Pre-K Children from Low SES Backgrounds. Early Childhood Education Journal, 46(2), 223-230. https://doi.org/10.1007/.s10643-0170845-y

Henderson, S. E., Sugden, D. A., \& Barnett, A. L. (2007). Movement Assessment Battery for Children-2 second edition (Movement ABC-2).
London, UK: The Psychological Corporation.

Hewson, S., Mcconkey, R., \& Jeffree, D. (1980). The relationship between structured and free play in the development of mentally handicapped child: A case study. Child: Care, Health and Development, 6(2), 73-82. https://doi.org/10.1111/ j.1365-2214. 1980.tb00799.x

Jaydari, M., Rouzbahani, M., \& Hasanvand, R. (2016). The effect of traditional games the development of transfer and manipulation motor skills in boys with mental retardation. International Journal of Physical Education, Sports and Health, 3(6), 134-136.

Jones, R., Okely, A., Hinkley, T., Batterham, M., \& Burke, C. (2016). Promoting gross motor skills and physical activity in childcare: A translational randomized controlled trial. Journal of Science and Medicine in Sport, 19(9), 744-749. https://doi.org/10.1016/j.jsams.2015.10. 006

Logan, S.W., \& N. Getchell. (2010). The relationship between motor skill proficiency and body mass index in children with and without dyslexia: A pilot study. Research Quarterly for Exercise and Sport 81(4), 518-23. https://doi.org/10.5641/027013610x130 88600029562

Logan, S. W., Robinson, L. E., Wilson, A. E., \& Lucas, W. A. (2011). Getting the fundamentals of 
International Journal of Childhood, Counselling, \& Special Education (CCSE), Volume1, Issue: 2, December: 2020, pp.204-223

movement: A meta-analysis of the effectiveness of motor skill interventions in children. Child: Care, Health and Development, 38(3), 305-315.

https://doi.org/10.1111/j.1365-

2214.2011.01307.x

Logan, S. W., Robinson, L. E., Rudisill, M. E., Wadsworth, D. D., \& Morera, M. (2014). The comparison of school-age children's performance on two motor assessments: The test of gross motor development and the movement assessment battery for children. Physical Education and Sport Pedagogy, 19(1), 48-59.

https://doi.org/10.1080/17408989.2012. 726979

Mackenzie, B. (2007). Developing Social and Emotional Skills through Movement. In K. P. Nonis \& S. Daswani (Eds.), The Power of Movement - Enhancing Children's Cognitive, Social and Emotional and Physical Development through Movement (pp. 112-128). Singapore, SG: Pearson Education, South Asia.

Ministry of Education (1988). Traditional Games. Singapore, SG: Curriculum Planning \& Development Division, Ministry of Education.

National Department for Culture and Arts (n.d.). Traditional Games. Retrieved December 1, 2020, from http://www.jkkn.gov.my/en/traditi onal-games
Newell, K. M. (1986). Constraints on the development of coordination. In M. G. Wade \& H. T. A. Whiting (Eds.), Motor development in children: Aspects of coordination and control (pp. 341 - 361). Dordrecht, NL: Martinus Nijhoff Publishers

Nonis, K. P. (2005). Kindergarten teachers' views about the importance of preschoolers' participation in sports in Singapore. Early Child Development and Care, 175(7-8), 719-742.

https://doi.org/10.1080/0300443042000 244000

Nonis, K. P., \& Tan, J. (2010). Young Children's Motor Skill Development in Outdoor Experiences. In M. Chia \& J. Chiang (Eds), Sport Science in the East: Issues, Reflections and Emergent Solutions. Singapore, SG: World Scientific Publishers.

Parten, M. B. (1932). Social participation among pre-school children. The Journal of Abnormal and Social Psychology, 27(3), 243269.

https://doi.org/10.1037/h0074524

Robinson, L., Palmer, K., \& Meehan, S. (2017). Dose-response relationship: The effect of motor skill intervention duration on motor performance. Journal of Motor Learning and Development, 5(2), 280-290.

https://doi.org/10.1123/jmld.2016-0004 
International Journal of Childhood, Counselling, \& Special Education (CCSE), Volume1, Issue: 2, December: 2020, pp.204-223

Santer, J., Griffiths C., \& Goodall, Tortella, P., Haga, M., Loras, H., D. (2007). Free play in early Sigmundsson, H., \& Fumagalli, G. childhood: A literature review. (2016). Motor Skill Development in National Children's Bureau. Italian Pre-School Children Induced London, UK. by Structured Activities in a Specific Sang, H. (2016). Life Before Pokemon Go? Iranians Still Enjoying Old Traditions. Retrieved from Retrieved November 20, 2020, from https://sputniknews.com/art living 201607201043355793-noPlayground. Plos One, 11(7), 1-15. https://doi.org/10.1371/journal.pone.01 60244

Ulrich, D. A. (2000). Test of Gross Motor Development $\left(2^{\text {nd }}\right.$ edition). Texas, US: Pro-Ed Inc.

pokemon-iran-tradition/ 